\title{
Ragtime and Anti-Bolshevism
}

\author{
Brian Holder \\ Santa Fe College \\ brian.holder@sfcollege.edu
}

\begin{abstract}
In 1918 the popular composer George Cobb published his "Russian Rag" - a ragtime rendition of Sergei Rachmaninoff's Prelude in C\# Minor. This work embodied the social and political concerns of the era, specifically global radicalism, immigration from Eastern Europe, and the use of ragtime as musical parody. Through an examination of this and other period works it can be shown that ragtime and popular song were used as a medium to conceptualize and transmit these concepts. Furthermore, this literature exhibits the rapid evolution of mainstream discourse on Russian immigrant culture in the years that followed the First World War.
\end{abstract}

Keywords: ragtime, Bolshevism, parody, Rachmaninoff

In 1986 the ragtime pianist Dick Wellstood recorded a live performance of George Cobb's (1886-1924) "Russian Rag", a work written in 1918 as a parody of Sergei Rachmaninoff's Prelude in C\# minor, Op. 3, no. 2. His performance ended with the following exchange between artist and audience:

I see you like - I see you like classical music? [Laughter] That was the Russian Rag. That was written by a man from Boston; Boston's own George L. Cobb. Cobb; C-O-B-B George L. Cobb. He used to work for the Boston Music Company. In 1918 he wrote that. [Pause] Well, you may remember they made a rock tune out of Beethoven's Ninth Symphony a few years ago - his is the same thing. You know Rachmaninoff wrote that Prelude in 1892 and this - eh - took 'em fifteen years to make a rag out of it. [Laughter] (Wellstood 1997.)

The track begins with mild applause, signifying that at least some portion of his audience recognized the tune (either Rachmaninoff's or Cobb's parody). Yet the above explanation was important enough to make it on to the final recording, as a part of the concert experience and as an instruction to later listeners. Wellstood reminded his audience that this music is a joke--a disguise through which to criticize the aesthetic experience of Rachmaninoff's music. He also allows us to question how seriously we want to take this music; Wellstood viewed the effect of ragtime through a more modern example--the comparison with the Beethovenian "rock tune". Like all music, one can hear the work however you want to, either as a musical spoof or a ragtime showpiece with no contextualization.

The "Russian Rag" was a contribution to the larger body of 'ragged classics' (art music interpreted in the style of ragtime) that often balanced high culture with low, European with American, and formality with exuberance. These selections displayed virtuosity and wit, and were intended to appeal to the musical knowledge and expectations of the listener. Cobb's work (which he called an "interpolation") had it all-virtuosity, flash, and a sustained popularity among his listening and performing public. 
It has been performed and recorded by many artists in its near 100 year history (See the appendix for recording information).

George Cobb made arrangements of other well known tunes (Such as Peter Gink, a takeoff on Edvard Grieg's Peer Gynt). So why was his "Russian Rag" such a hit? And why single out Rachmaninoff for parody? Yes, the Prelude was a well known composition with a memorable introduction, but in essence, Cobb's work spoke to the moment and resonated with the new world carved out by the First World War. The "Russian Rag" became a small part of the then-contemporary dialogue concerning global politics, immigration and radical social ideologies. As American soldiers became involved in the European War, so too did American minds tackle the problems of the old world. For some, these issues came alive in the United States - either in fact or in a theater-of-the-mind experience.

One of the greatest social and political dangers of the First World War years was Bolshevism. This political ideology became a pop culture obsession in the United States. Paul McCann's article in the Journal of Popular Culture examines a 1922 short story, "The Jazz Baby" (McCann, 2008, pp. 658-675). The tale was originally published in the Saturday Evening Post, and is quoted by McCann as follows:

Overwhelmed at first by the mere volume of barbaric sound [produced by her son's saxophone] she found herself after a time trying to analyze jazz. It seemed to her to be musical Bolshevism-a revolt against law and order in music. Apparently, too, the jazz Bolsheviks were looters, pillaging the treasure houses of music's aristocracy. One piece was based on a Chopin waltz, another was a distortion of an aria from Tosca... Was there a connection between the various disturbing elements-free verse, futuristic painting, radicalism, crime waves, obstreperous youth, jazz music, jazz dancing, jazz thinking (2008, p. 662).

McCann notes that this character is "a wealthy traditionalist who fears the potential threat posed by Communism to her standard of living and way of life", yet "the irony of course is that . . . the revolutionary underclass ... has no fictional representation within the narrative but exists only as a figment of her paranoid imagination" (ibid.). Additionally, the transformation of European art music into jazz crosses many wires, confusing the final product. On the surface, a "ragged classic" is dance music inspired by past classics, but also represents various social ailments and fears, specifically Bolshevik ideology. This is a typical statement of the era. The quote expresses fear and misunderstanding-two emotions that can easily be focused towards a threat. "Musical Bolshevism" is the embodiment of radicalism, proletarianism, a break from tradition, and a disregard for the established boundaries of society and musical hierarchy. George Cobb touched upon this social pulsation through his "ragged classic", and produced a statement that was musically, politically and culturally loaded.

During the last months of 1917, Sergei Rachmaninoff became increasingly aware of the escalating political instability of the Russian Provisional Government. Civil unrest at his Ivanovka estate motivated the family to relocate to a flat in the soon to be capital city of Moscow. It would not be long before the pianist would leave Russia entirely. That November, Rachmaninoff received an offer for a brief concert tour in Scandinavia. This minor concert tour, which the pianist would otherwise have declined, provided a means to leave the country that was not afforded to other artists. Rachmaninoff had some difficulty in obtaining a visa, but he and his family were able to make the trip and ultimately escape Russia and the burgeoning civil war.

Because of this concert series, Sergei Rachmaninoff and his family fled a dying Czarist Russia and headed west. Stockholm and Copenhagen became their temporary homes until they arrived in the United States on 1 November 1918, one year after their 
flight had begun. The Rachmaninoff family left their political woes behind, but their lost financial security motivated the pianist to perform as much as possible rather than spend time in composition. He played concerts frequently and also became a Victor Talking Machine Company recording artist. Within a few years, the family was financially stable enough to purchase a house in New York City, which allowed them to recreate their lost estate Ivanovka. It was here that they observed old world customs, employed Russian servants and offered a cultural oasis for other émigrés.

The Rachmaninoff family was one of many Russian expatriates who opposed Vladimir Lenin's Bolshevik party and yearned for a return to Czarism—-they belonged to a category known as White Russians. The Revolution, which inspired this political division between Red and White, produced mixed emotions among many American citizens, some of which had difficulty distinguishing between recent émigrés and Lenin's Socialist Revolutionaries. In December 1919 the New York Times ('Beat Bolshevism') offered an explanation of this effect:

\begin{abstract}
There are in this city 60,000 Russians ... Most of them live on the lower east side. The real majority of them are illiterate and the popular conception of them (not perhaps wholly an unjust one) is that they are "mostly Bolsheviks." . . Why? To begin with, the 60,000 , most of them being comparatively recent immigrants, are not only illiterate and ignorant, but are in a state of mind which reflects the upheaval in their mother country. Thus they are peculiarly susceptible to the blandishments of the Bolshevik or the Bolshevisticly [sic] inclined.
\end{abstract}

This article went on to illuminate the way in which Russian immigrants were highly susceptible to Bolshevik influence unless they were offered an American alternative. It is instructive to note how Bolshevism was also applied to all recent immigrants, regardless of social standing or economic background. This was not uncommon during these years, as witnessed in the following letter to the New York Times (1919, p. 38) that defended Russian-Americans against this prejudice:

\begin{abstract}
The impression that all the Russians in America are Bolsheviki is gaining credence in wide circles of American public opinion. ... This is so, in fact, to such an extent that manufacturers and business men are beginning to "cleanse" their establishments of the "Russian element," considering their Russian employees as "Bolsheviki". . . . Being 'laid off' on account of being a Russian is surely the best kind of anti-American propaganda any Bolshevik would ever desire.
\end{abstract}

This rhetoric abounded in the final years of the war, a period known as 'the Red Scare'. In this atmosphere, Russian cultural stereotypes became representative of an imagined society ruled and solely populated by the anarchistic 'Bolsheviki'. To an increasingly xenophobic American public, White Russians and their cultural baggage were subsumed under this stereotype.

As Rachmaninoff and his family were emigrating to the United States, George Cobb was creating his arrangement of the pianist's Prelude in C\# minor, op. 3, no. 2. This work, the aforementioned "Russian Rag", fed off the popularity and public awareness of Rachmaninoff's Prelude (Jasen, 1998, p. 88), which he first performed in the United States during a 1909 concert tour--nearly ten years before he and his family emigrated. During this lapse of time the American public did not forget the Russian virtuoso, and kept his celebrity alive via the Prelude. The work lived on in music studios, cafes and other formal and informal performances. In the years before 1917 the Prelude became an embodiment of the composer that was recreated with each performance. The Prelude was Rachmaninoff for many American audiences, a fact that George Cobb was certainly well aware of. The appeal of the short work overshadowed Rachmaninoff's other compositions, which caused him to loath its seemingly obligatory performance at his recitals. By 1924 he revealed that he was 
"sickened" by the sound of his Prelude, owing specifically to its appropriation as "popular amusement"; he stated in clear terms that "I don't even like to play it any more, much less hear it" (New York Times, 1924, p. 10).

George Cobb based his rag on the introductory material of the Prelude, quoting the three-note motif A-G\#-C\# (transposed to Bb-A-D, see figures 1 and 2). $\mathrm{He}$ interpolated this quote with several rhythmic figures that offered typical ragtime syncopation and rhythmic organization.

\section{Prelude I}
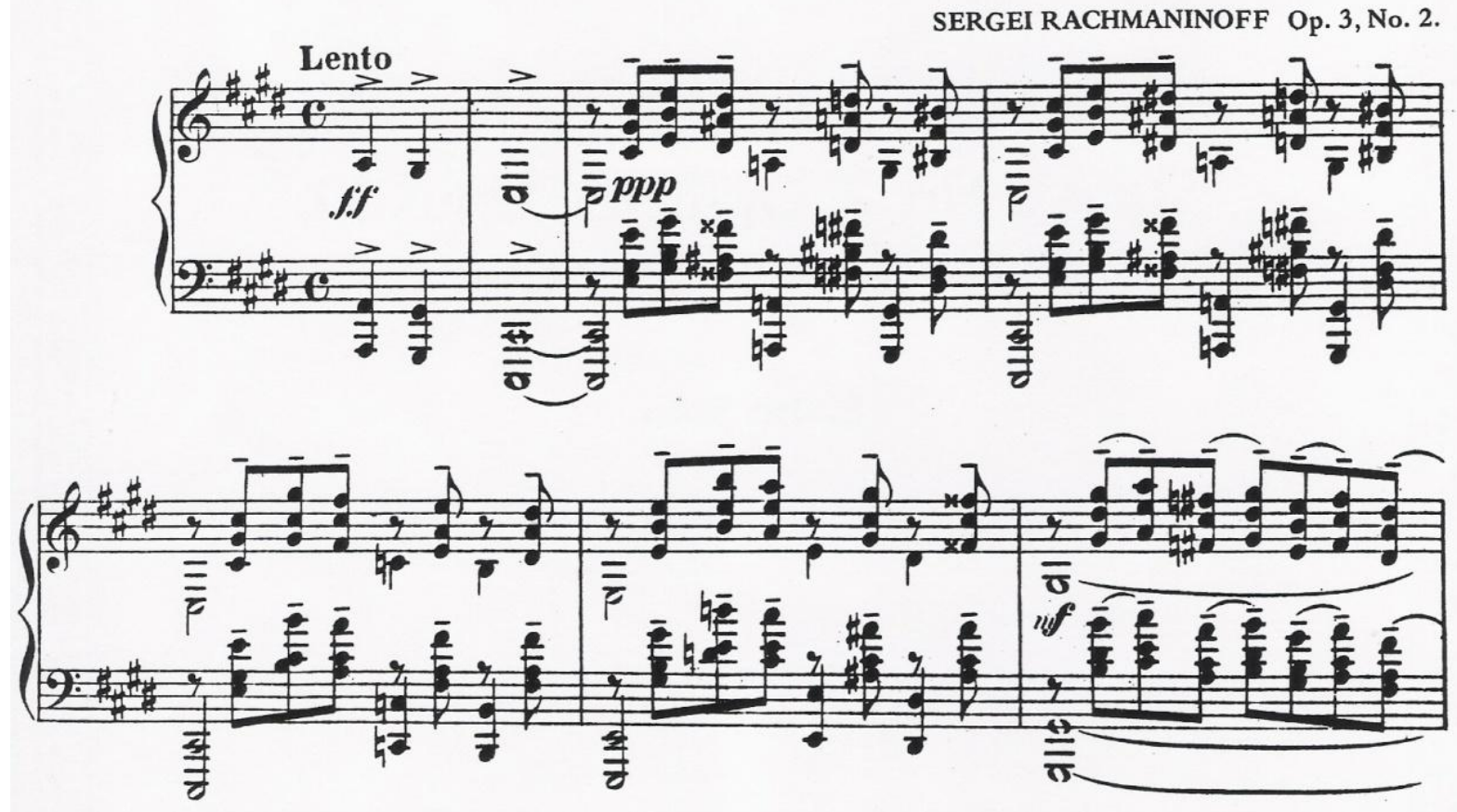

Figure 1 - Sergei Rachmaninoff, Prelude in C\# minor, op. 3, op. 2, mm. 1-6. 


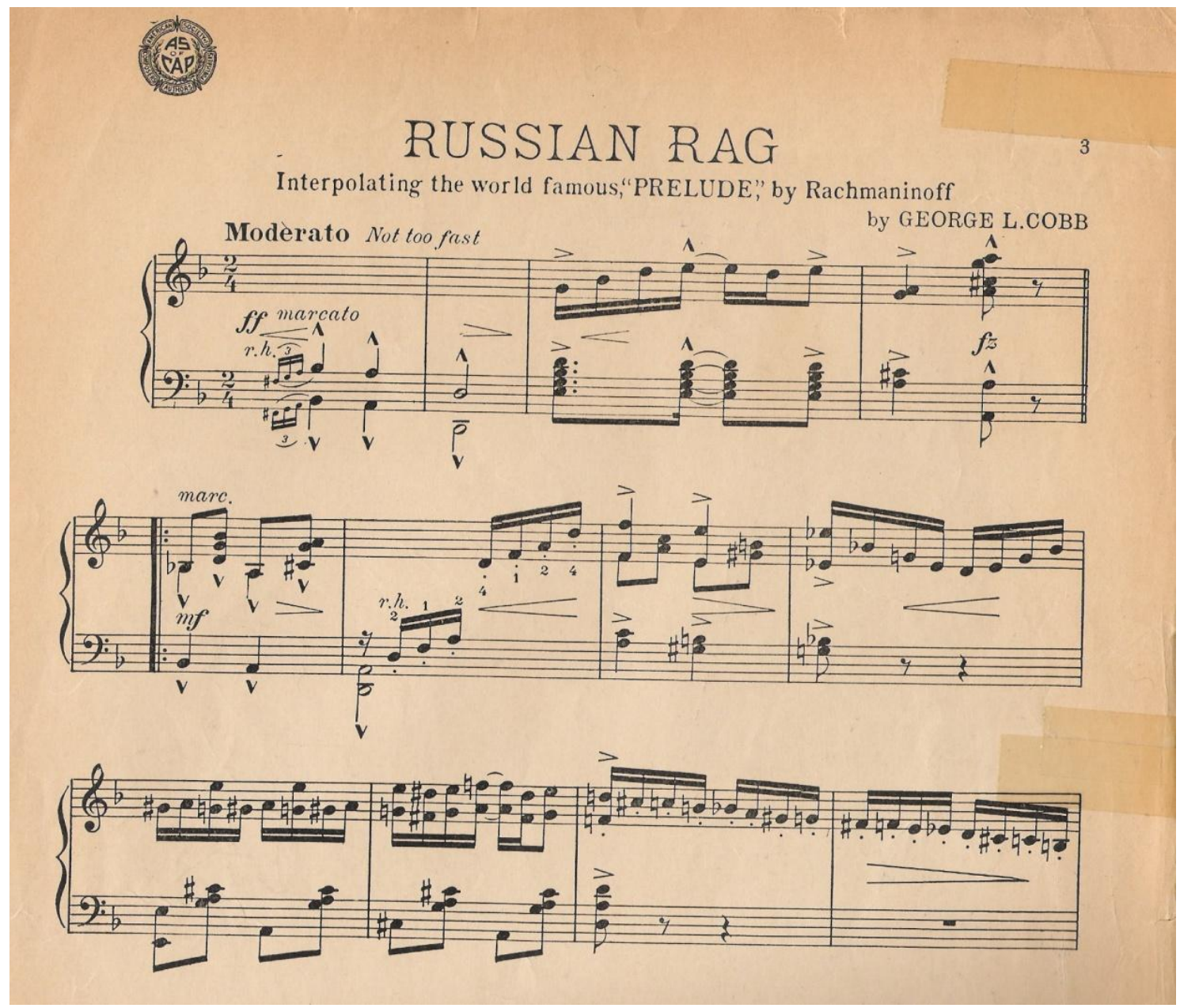

Figure 2 - George L. Cobb, Russian Rag, mm. 1-12.

As previously mentioned, Cobb called this work an interpolation, and it was a playful abuse of the Rachmaninoff image. But Cobb did also tap into the public discourse on radical politics. His rag had no overtly anti-Bolshevik message, but the work entertained stereotypes of Russian culture then associated with the Revolutionaries. An image of the dancer Rhea McMurray graced the sheet music cover (see figure 3). She performed under the stage name of Mademoiselle Rhea, which was an imitation of the famous ninetweenth century French dancer and actress of the same name. The original Mlle. Rhea was born Hortense Barbe Loret in 1845 and maintained an active career both in Europe and North America (Londré, 2007, p. 144). After an 1883 performance in Kansas City the child Rhea McMurray was named after the celebrity dancer. This second Mlle. Rhea went on to a less star-studded dancing career in New York City, yet assumed the stage moniker of her namesake for professional purposes (ibid., p. 144).

Interestingly, both Mlle. Rheas studied dance in the then Russian capital city, St. Petersburg. This was no coincidence, as prior to her North American debut Hortense Loret had launched her career in St. Petersburg, and Rhea McMurray wished to follow the example of her namesake. This professional mimicry informs Rhea's image on the cover of the Russian Rag (figure 3). She is seen both in traditional ballet dress and in what appears to be folkloric Russian garb - representative of the upper and lower classes of Russian society. This emphasis on the Russian element within the piece did more than draw a connection to Rachmaninoff. It embraced a popular conception of the broad sweep of Russian society, which was then being attacked as a 
subversive element in the United States. Especially noticeable are the Russian bootlegs-which became an American fashion trend in the 1920s.

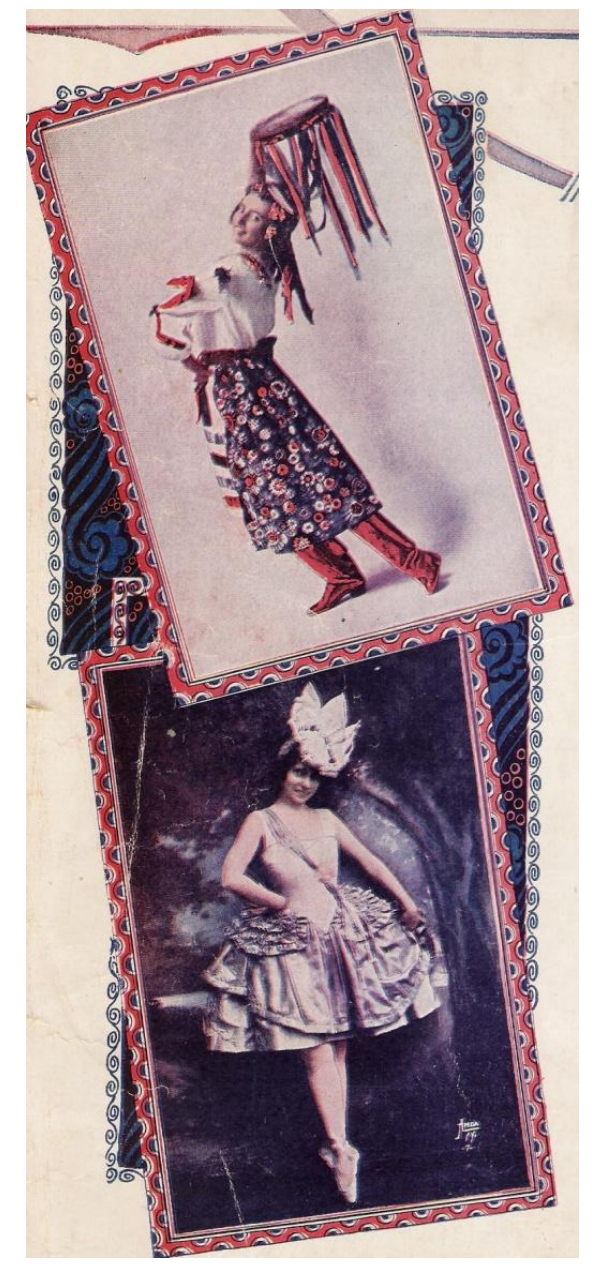

Figure 3 - Rhea McMurray from the cover of the Russian Rag.

As the score indicates, the "Russian Rag" was further endorsed by the Six Brown Brothers Clown Band (see figure 4). This well regarded minstrel troupe performed the rag arranged for saxophone ensemble-the group's signature presentation. The Brown Brothers never recorded Cobb's rag, but they did feature it in many performances. Their popular 1920 show Tip Top included a scene that remained constant through later Brown Brothers performances. Tom Brown, the group leader, described the use of the "Russian Rag" within this scene:

Then I walk as though I was going to leave them [the rest of the band] when I hear them start to play SWEET ADELINE I turn back smilingly and do the DIRECTING to SWEET ADELINE (which is a big success) then at the finish of the directing after I do the scratching (Which gets a big laugh-) I run off and take off the bridal veil and get back in time to line up for the RUSSIAN RAG which is the finish of the act. Of course we do the dance with the rag which helps to put it over (Vermazen, 2004, p. 147).

The rag must have been a powerful curtain-closer. The Brothers performed and recorded another similar rag by George Cobb, Peter Gink. 


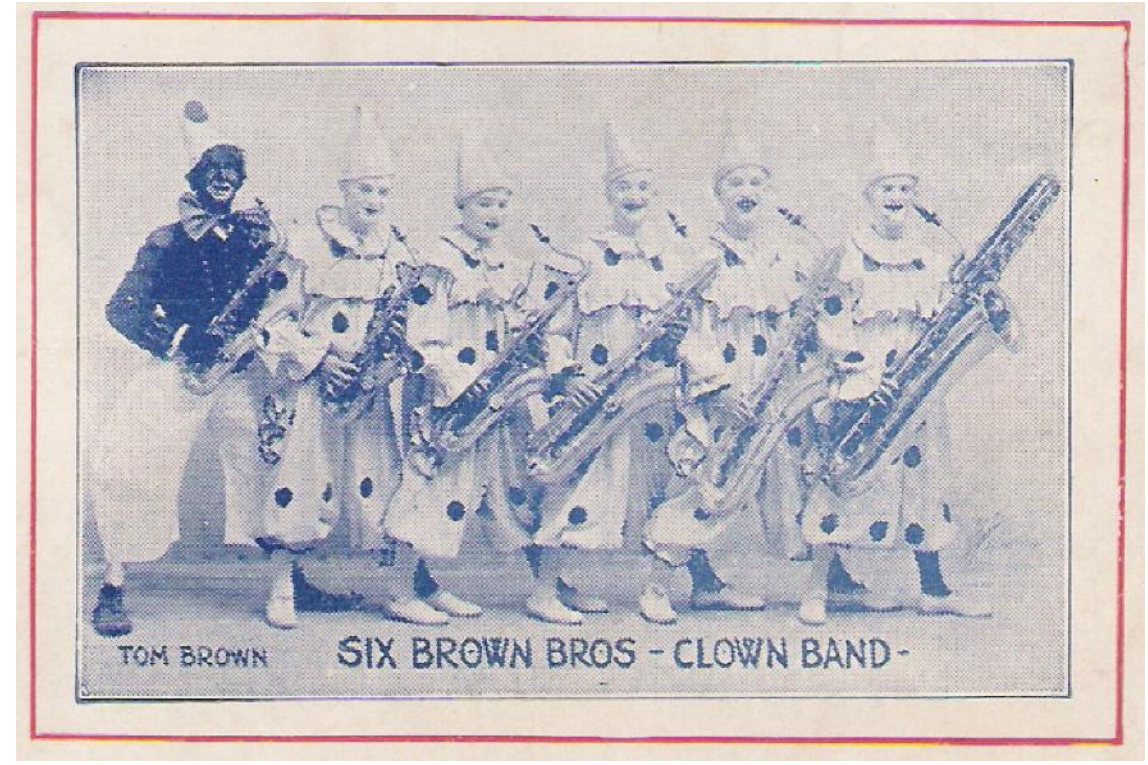

Figure 4 - The Six Brown Brothers Clown Band as featured on the cover of the Russian Rag.

John Philip Sousa was also inspired by the Russian Rag. The bandleader began featuring a saxophone sextet, much in emulation of the Brothers' popular success, and Cobb's rag became one of several "popular syncopated melodies" transferred to the Sousa book (Vermazen, 2004, p. 135). The rag became increasingly popular as numerous other artists arranged and recorded the parody. The first was by Earl Fuller and his orchestra, followed by a similar treatment by the Emerson Military Band. Diero Pietro also offered his version for accordion solo on the Victor label that year. Most famously, a recording made by James Reese Europe and the "Hellfighter" Band propelled the rag to international fame. This rendition, billed as a foxtrot, was released on disk by the Pathé Actuelle Company.

Within a few years Cobb's rag accrued such fame that he was pushed to create a sequel. Thus, the New Russian Rag was published by Will Rossiter and reached the American public in 1923. This was a more "pyrotechnical" rendition of the popular prelude that catered to the virtuosic demands of vaudeville piano soloists (Jasen, 1988, p. 176). It also contained more of Rachmaninoff's original content than the first Russian Rag (see figures 5 and 6). The sequel, however, was not as fresh as the original and enjoyed little commercial success. Cobb's first "Russian Rag" continued to be rearranged throughout the 1920s, as late as Roy "Wizard of the Strings" Smeck's 1928 arrangement for banjo and piano, or John Krachtus's accordion arrangement from the same year (see figure 7).

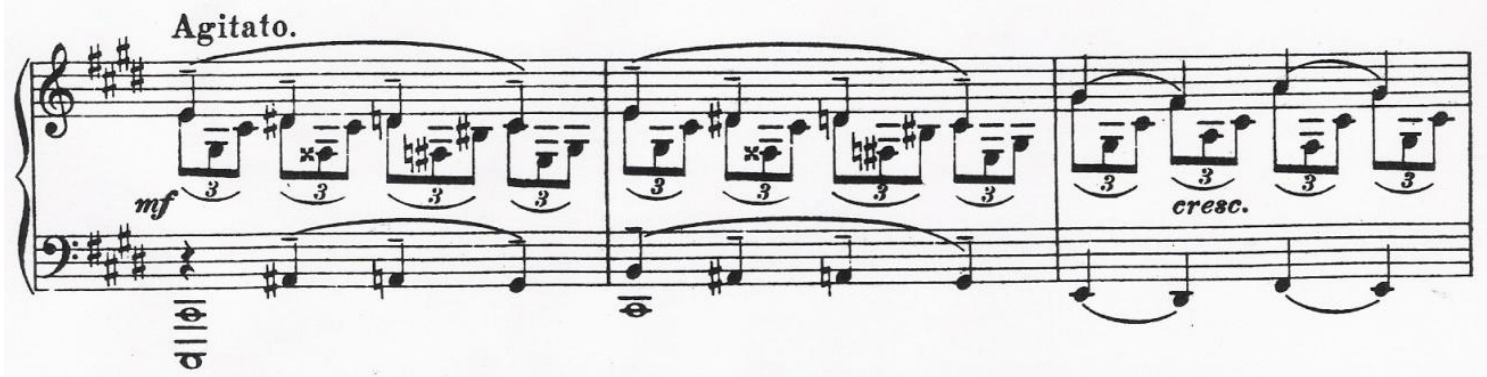

Figure 5 - Sergei Rachmaninoff, Prelude in C\# minor, op. 3, no. 2, mm. 15-17. 


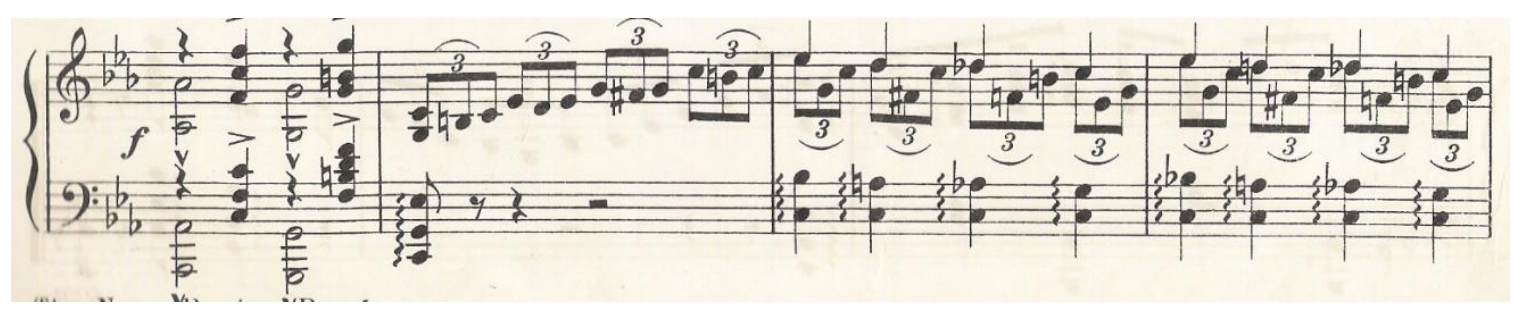

Figure 6: George L. Cobb, New Russian Rag, mm. 76-79.

Cobb's rag was born during a moment of heated public opinion regarding Russian culture in the United States. Yet this issue lost its intensity as the American Red Scare ran out of political steam (circa 1920) and the Russian Civil War came to an end (in 1923). Anarchist-inspired bombings, government raids and mass deportations of suspected radicals had ceased by the mid-1920s. What did remain were the images and stereotypes propagated during the post-war years - images that would shape the American perspective of Russian culture and immigration patterns for years to come. The song "Bolshevik" is one such example of this progression (see figure 8). It was introduced and recorded in 1926 by Fred Waring and his Pennsylvanians, a group popular among the student body of Pennsylvania State University and throughout the United States. Waring and his band cut this track for the Victor Company on 20 August, in which they presented their own interpolation of the college hit. As the recording reveals, the Pennsylvanians introduced a quotation from Rachmaninoff's Prelude during the introduction to "Bolshevik" (see figure 9). This was not in the original published song sheet, but the recording itself is full of other artistic liberties such as vocal effects (specifically, a teeth solo). The interpolations of the printed score are not as important as the link created between the cultural implications of the "Russian Rag" and "Bolshevik". By quoting the introduction to Rachmaninoff's Prelude, the band was also quoting Cobb's rag. It is safe to assume that Bolshevik's audience would have been at least in part familiar with Cobb's popular work as it was continually performed, arranged, and recorded throughout the 1920s. 


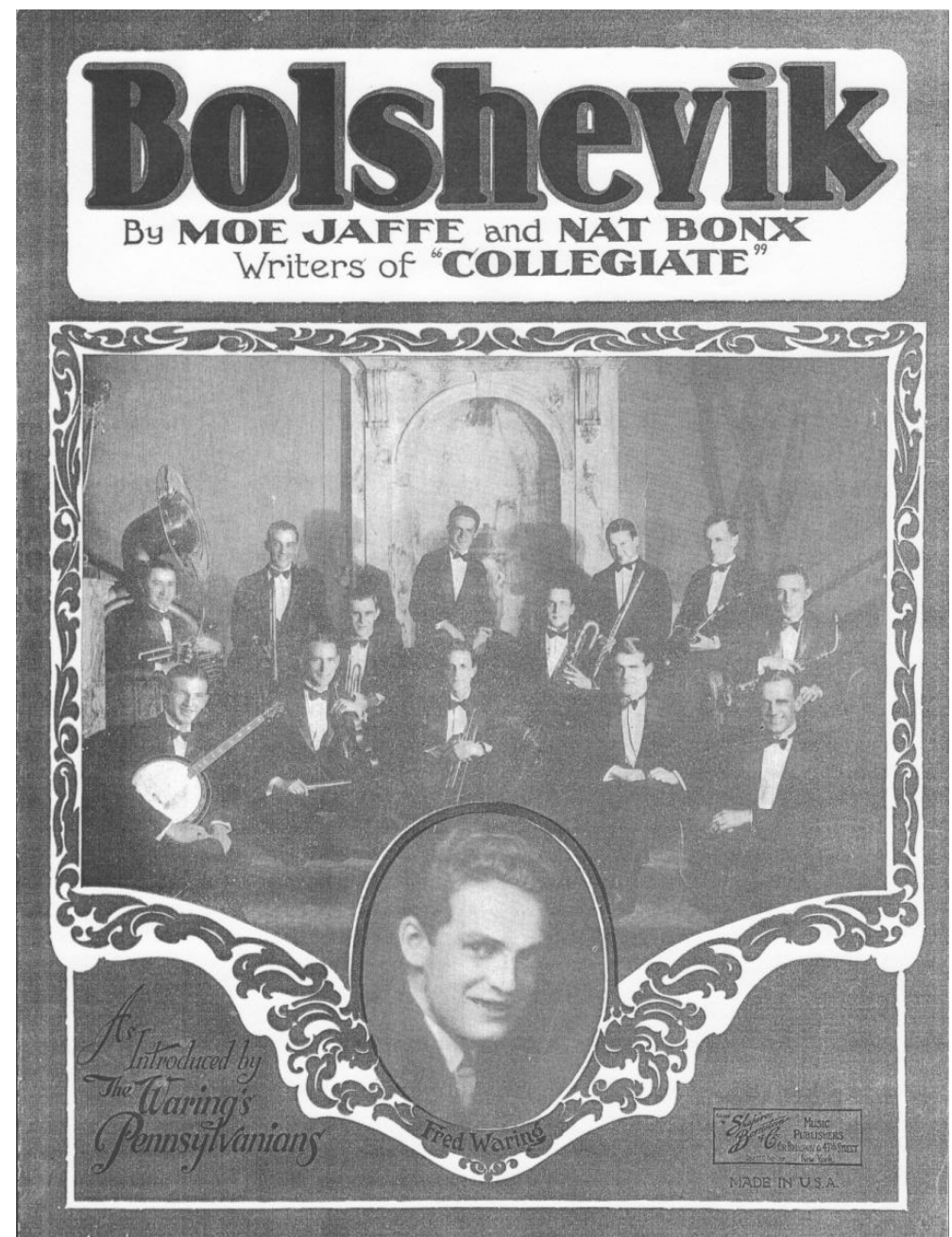

Figure 7 - Bolshevik cover.

(Courtesy of Fred Waring's America, Special Collection of Penn State University Libraries.)

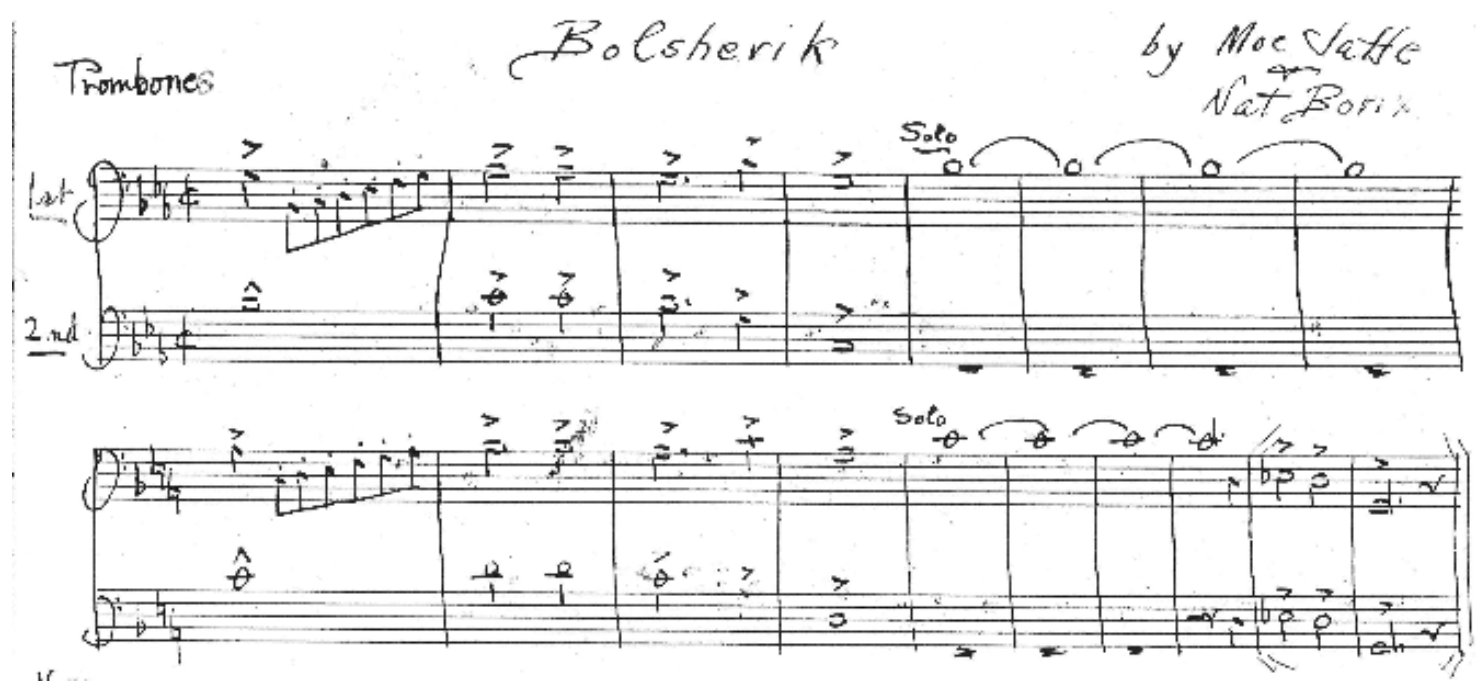

Figure 8 - The trombone part to Nathan Bonx and Moe Jaffe's Bolshevik, mm. 1-18. Rachmaninoff is quoted in the final two measures of the excerpt.

(Courtesy of Fred Waring's America, Special Collection of Penn State University Libraries.) 
Bolshevik is a tongue-in-cheek take on Russian culture in mid-1920s America. The use of the Prelude/"Russian Rag" theme was a reminder--a means by which to transfer the imagery of the Red Scare to a time in which Bolshevism was no longer a domestic terror. This connection reinforced the negative Russian stereotypes found within the song text by projecting the ideologies of the Red Scare into a later time frame. The song specifically engages the conceptions of Russian dance, drink, personal appearance and speech. Yet "Bolshevik" remained a lighthearted songderogatory certainly, but not a fearful presentation of the Russian Bolsheviki. Radicalism is presented only through the images of the former years, with only a playful sense of negativity to keep the door open for an assault on Bolshevism.

The novelty of Russian dance was not a singular obsession at a time when numerous dance crazes swept the United States. This was rather one small part of a trend that included many popular dances from around the world and the much noted animal dance mania that spawned the fox trot, grizzly bear, turkey trot, etc (George Cobb contributed the "Bunny Hug Rag"). Contemporary dance manuals provided the willing amateur with the details needed to reproduce their own Russian dances. A triple foot stomp is one of the most distinctive elements of this instruction. The dancers were instructed to "slap hands 3 times over shoulder nearest to partner, at same time stamp feet 3 times" (Clendenen, 1919, p. 126). This percussive effect was important to the dance's identity as a Slavic activity, as echoed in later dance manuals (one example is Bergman). A representation of this idea can be found in "Bolshevik" (see figure 10).

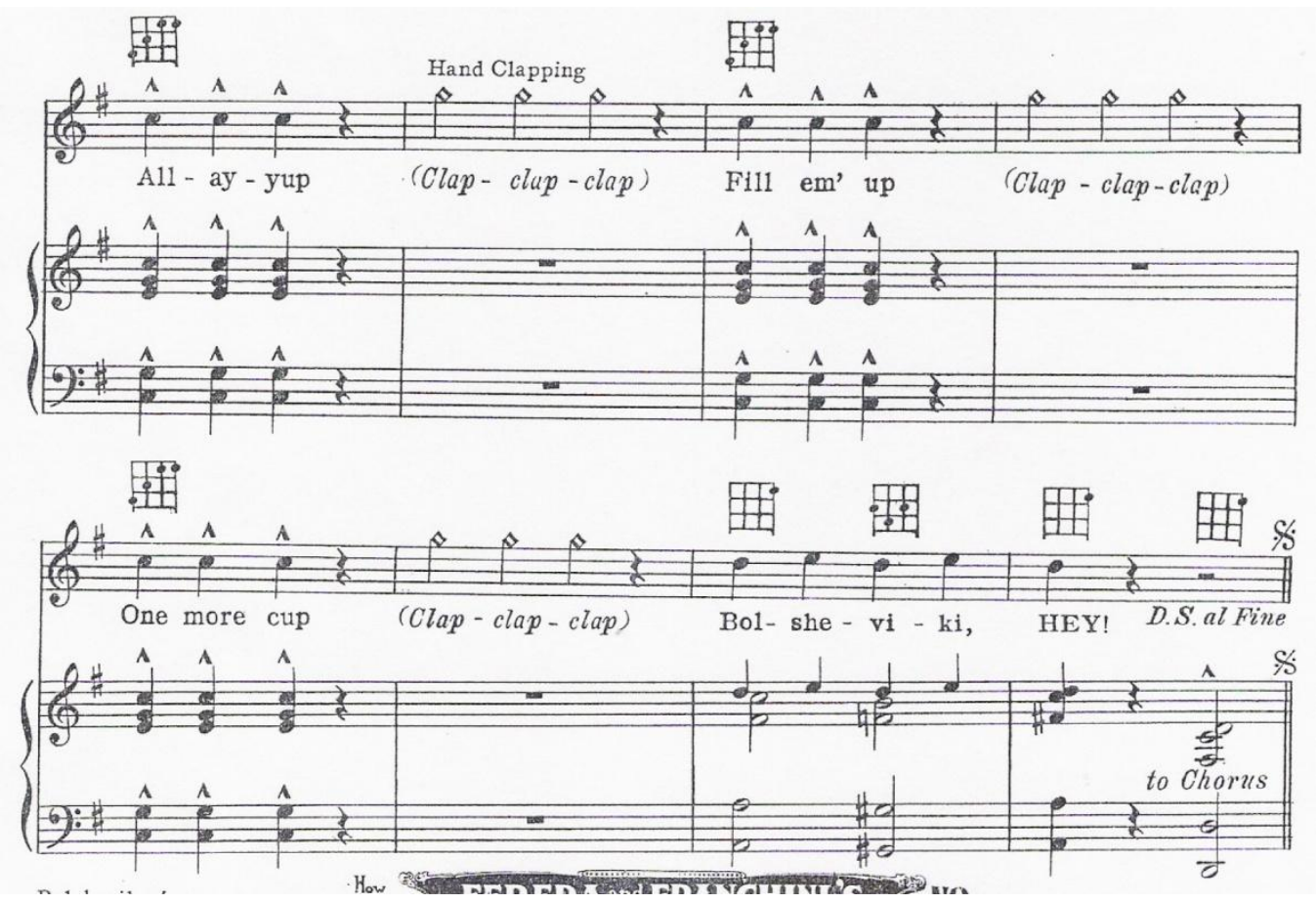

Figure 9 - Moe Jaffe and Nat Bonx, Bolshevik, mm. 71-78.

(Courtesy of Fred Waring's America, Special Collection of Penn State University Libraries.)

The "Bolshevik" lyrics constantly abused stereotypical Eastern Europe literary suffixes; "-sky" was the specific additive, and contributed to ridiculous phrases such as "I come from across-sky the sea," and "I will take a tax-sky now." The most concentrated portion of the song is the patter section called the "Patter-ewski" (an obvious play on Ignacy Paderewski (1860-1941), the famed Polish pianist and diplomatic champion of Polish sovereignty in post-War Europe): 
[Patter-ewski]
Hey pass-ky me-sky the whis-key,
I'm-sky Motka from-sky Slabotsky,
I must have-sky some-sky Shabotka,
With-sky my-sky glass-sky of Vodka.

The song lyrics reference several other stereotypical images. The Russian male prejudice for wearing beards is singled out in several lines:

Far far away

In that Bolsheviki land-o-vitch,

They never shave,

So they never get the barber's itch. ...

They all wear beards

So they can not tell just which is which.

Jaffe and Bonx's Bolshevik construction also features a then current social danger, although this danger does not involve political ideology or industrial revolution. Their idealized Russian drinks heavily, fulfilling yet another stereotype:

I come from a-cross-ky the sea,

Oh! I'm a Bolshevik

The land-ski of Vodka and Tea,

And stuff that has a kick....

When they take a drink (Hup)

They don't stop to think (Hup)

They don't use their head (Hup)

'Cause their brains are dead (Hup).

None of this imagery alluded to any real political danger. Instead, this selection presents the stereotypical Russian Bolshevik as an image to be mocked and looked down upon--a drunk and disorderly character worthy only of shame before the haughty stature of American culture (not unlike the stereotypical images of other ethnic groups). For its negativity, "Bolshevik" does not warn of any imminent Bolshevik invasion or infiltration into American society; it is a jab at the then popular perspective of Russian culture in the United States. But the emotions of the Red Scare certainly informed the later song, overshadowing its frivolity with a darker social message.

There were many other musical statements about Russian culture in the United States (Irving Berlin's 1927 "Russian Lullaby" being one of the most well known), and some have enjoyed a longer performance history than others. The "Russian Rag" lives on as a ragtime staple, which performers and audiences continue to enjoy. The work is also a means by which to have some fun with the music of Rachmaninoff, whose Prelude is still a recognizable work played by numerous pianists. Further below the surface, however, the Russian Rag betrays traces of an era in which Russian immigration and communist ideology posed a threat to the established American social order and became an object of mockery and derision. It can take the listener back to a more politically incorrect time, when images of Russian culture entered into the mainstream political discourse not to represent actual immigrants entering into the United States, but the extreme political situation from which they fled. 


\section{References}

Bergman, Marion. 1947. The Russian-American Song and Dance Book. A.S. Barnes and Company, New York.

Clendenen, Leslie F. 1919. The Art of Dancing: Its Theory and Practice. Arcade Print Shop, St. Louis.

Jasen, David A. 1988. Tin Pan Alley, The Composers, The Songs, The Performers and Their Time, D.I. Fine, New York.

Londré, Felicia Hardison. 2007. The Enchanted Years of the Stage: Kansas City at the Crossroads of American Theater, 1870-1930, University of Missouri Press, Columbia.

McCann, Paul. 2008. "Performing Primitivism: Disarming the Social Threat of Jazz in Narrative Fiction of the Early Twenties". The Journal of Popular Culture, Vol. 41, No. 4: pp. 658-675.

New York Times. 1919. "Beat Bolshevism In Its Best Field", 28 December, E2.

New York Times, 1919. "Bolshevism And Russians Here", 15 June, 38.

New York Times. 1924. "Election Pleases Sir Henry Lunn”, 31 October, 10.

Tichenor, Trebor. 1978. Rags and Ragtime, a Musical History, Seabury Press, New York.

Vermazen, Bruce. 2004. That Moaning Saxophone: The Six Brown Brothers and the Dawning of a Musical Craze, Oxford University Press, Oxford.

Wellstood, Dick. 1997. Dick Wellstood Live at the Sticky Wicket, Arbors Jazz. 